\title{
PERAN MOTIVASI KERJA DALAM MEMEDIASI PENGARUH PENGEMBANGAN KARIR TERHADAP KINERJA KARYAWAN
}

\author{
I Gede Made Yudi Suryawan ${ }^{1}$ \\ I Gusti Made Suwandana ${ }^{2}$ \\ ${ }^{1,2}$ Fakultas Ekonomi Dan Bisnis Universitas Udayana (Unud), Bali, Indonesia \\ email: yudisuryawan25@gmail.com; gungdesuwandana@unud.ac.id
}

\begin{abstract}
ABSTRAK
Penelitian ini dilakukan di PT Sejahtera Indobali Trada Cabang Tabanan. Jumlah sampel yang diambil sebanyak 54 orang karyawan, dengan metode yang digunakan adalah sampel jenuh. Pengumpulan data diperoleh dari hasil wawancara dan penyebaran kuesioner. Teknik Analisis data menggunakan uji asumsi klasik, analisis jalur (path analysis), uji sobel dan uji VAF. Hasil dari penelitian adalah Pengembangan karir berpengaruh positif dan signifikan terhadap motivasi kerja karyawan. Pengembangan karir berpengaruh positif dan signifikan terhadap kinerja karyawan. Motivasi kerja berpengaruh positif dan signifikan terhadap kinerja karyawan. Motivasi kerja berpengaruh positif dan signifikan dalam memediasi hubungan antara pengembangan karir terhadap kinerja karyawan.
\end{abstract}

Kata kunci: pengembangan karir, motivasi kerja, kinerja karyawan

\begin{abstract}
This research was conducted at PT Sejahtera Indobali Trada Tabanan Branch. The number of samples taken is 54 employees, with the method used is a saturated sample. Data collection was obtained from the results of interviews and questionnaires. Data analysis techniques used the classic assumption test, path analysis (path analysis), sobel test and $V A F$ test. The results of the study are career development has a positive and significant effect on employee motivation. Career development has a positive and significant effect on employee performance. Work motivation has a positive and significant effect on employee performance. Work motivation has a positive and significant effect in mediating the relationship between career development and employee performance.

Keywords: career development, work motivation, employee performance
\end{abstract}




\section{PENDAHULUAN}

Segala aspek kehidupan dituntut untuk bersaing menjadi yang terbaik, karena yang terbaiklah yang akan menguasai pasar dalam era globalisasi saat ini. Perusahaan seharusnya mempersiapkan diri untuk menghadapi tantangan yang ada dan sumber daya manusia dalam hal ini memiliki peran yang besar agar tujuan dari perusahaan itu dapat tercapai, oleh karena itu seorang karyawan harus memiliki kinerja yang baik agar perusahaan dapat menjadi suatu organisasi yang efektif dan efisien dan dapat bersaing dengan para pesaingnya.

Bianca et al. (2014) menyatakan bahwa arus globalisasi mengakibatkan adanya berbagai perubahan yang menuntut tenaga kerja menguasai teknologi baru, waktu kerja yang lebih efisien, perubahan tuntutan terhadap kinerja serta perubahan dalam peraturan kerja yang dapat menimbulkan situasi yang menekan tenaga kerja yang bersangkutan. Menurut Rayadi (2012), sumber daya manusia merupakan elemen yang sangat penting dalam satu perusahaan. Kegagalan mengelola sumber daya manusia dapat mengakibatkan timbulnya gangguan dalam pencapaian tujuan organisasi, baik kinerja, profit, maupun kelangsungan hidup organisasi. Manajer seharusnya mengerti bahwa keberhasilan dalam meningkatkan kinerja dan produktivitas harus melibatkan karyawan karena karyawan tidak hanya menjadi kekuatan utama dalam mewujudkan perubahan, tetapi juga semakin aktif berpartisipasi dalam merencanakan perubahan tersebut (Robbins \& Judge, 2008:143).

Oduma \& Were (2014) menyatakan bahwa seorang pimpinan yang mengharapkan pencapaian kinerja maksimal di organisasinya harus memperhatikan faktor-faktor yang mempengaruhi kinerja pegawai itu sendiri, salah satunya adalah pengembangan karir (career development). Pengembangan karir merupakan pendekatan formal yang dilakukan organisasi untuk menjamin orang-orang dalam organisasi mempunyai kualifikasi, kemampuan, dan pengalaman yang cocok ketika dibutuhkan (Kasegar, 2013). Perencanaan dan pengembangan karir yang jelas dalam organisasi akan dapat meningkatkan motivasi kerja pegawai dalam menjalankan pekerjaannya, sehingga menciptakan rasa puas dalam melaksanakan pekerjaannya (Nugroho \& Kunartinah, 2012). Dengan standar hidup yang lebih baik, karyawan tidak akan puas jika hanya memiliki pekerjaan dan tunjangan yang biasa. Para karyawan menginginkan karir yang mengungkapkan minatnya, kepribadiannya, kemampuannya dan yang selaras dengan keseluruhan situasi kehidupannya. Asriningtyas (2016) menyatakan bahwa pengembangan karir di PT. Inti Sukses Garmindo Tbk Semarang memiliki pengaruh signifikan terhadap kinerja karyawan. Tetapi, sebagian besar manajemen telah gagal untuk mengenali kebutuhan ini dan pengalaman yang diberikan tidak memungkinkan untuk mengembangkan karir karyawan (Nzuve, 2007). Florence (2007) dalam penelitiannya menyatakan bahwa pengembangan karir merupakan metode perencanaan terorganisir yang digunakan untuk menyesuaikan tujuan karyawan dengan kebutuhan bisnis dari suatu organisasi.

Penelitian yang dilakukan oleh Zameer et al. (2014) menemukan bahwa peran motivasi kerja sangat vital untuk meningkatkan kinerja karyawan pada industri minuman di Pakistan. Pimpinan wajib memperhatikan karyawan, 
mengarahkan serta memotivasi untuk meningkatkan kinerja karyawan. Motivasi kerja karyawan sangat dibutuhkan guna meningkatkan kinerja pegawai itu sendiri. Larasati \& Gilang (2014) menyatakan bahwa motivasi berpengaruh positif dan signifikan terhadap kinerja karyawan. Damayanti \& Sumaryati (2013) menyatakan terdapat pengaruh yang signifikan motivasi kerja terhadap kinerja karyawan PDAM Surakarta. Muogbo (2013) menyatakan bahwa pemberian motivasi bagi para pekerja dalam suatu organisasi dapat berpengaruh dengan signifikan terhadap kinerja para pekerja di Anambra State Nigeria. Nurcahyani \& Adnyani (2016) menunjukkan bahwa motivasi secara positif berpengaruh signifikan terhadap kinerja karyawan. Hal tersebut mengimplikasikan bahwa apabila pemberian motivasi berjalan dengan baik maka dapat memengaruhi tingkat kinerja karyawan Menurut Riyanti \& Sudibya (2013) motivasi berpengaruh paling besar terhadap kinerja karyawan pada Rumah Sakit Umum Dharma Usadha. Pegawai akan memberikan banyak imajinasi, keterampilan dan perhatian dalam pekerjaannya, untuk itu perlu diberikan motivasi bagi karyawan baik secara fisik maupun non fisik. Dengan terpenuhnya kebutuhan tersebut maka pegawai secara fokus dapat menjalankan tugas dan tanggung jawab yang diemban, untuk itu dibutuhkan suatu dorongan bagi pegawai dalam suatu organisasi Menurut Marwansyah (2014). Karyawan harus diberikan dorongan dalam bentuk motivasi, misalnya diberikan penghargaan seperti pengembangan karir, promosi, maupun insentif. Salah satu strategi yang harus diimplementasikan oleh pihak manajemen adalah membuat perencanaan dan pengembangan karir bagi karyawan selama bekerja di perusahaan. Beberapa karyawan menganggap peningkatan dalam berkarir adalah hal yang sangat krusial karena karyawan akan mengetahui di mana posisi tertinggi yang akan diraih, sehingga karyawan tersebut akan terus termotivasi dan terus berusaha meningkatkan skill dan loyalitas terhadap perusahaan. Organisasi harus memotivasi karyawannya untuk kinerja terbaik atau untuk mencapai tujuan organisasi, bahkan motivasi adalah alat terbaik untuk kinerja terbaik (Zameer et al., 2014).

Penelitian ini dilakukan di PT. Sejahtera Indobali Trada Cabang Tabanan yang merupakan salah satu perusahaan yang bergerak di bidang industri otomotif. Tujuan dari penelitian yang dilakukan di PT. Sejahtera Indobali Trada Cabang Tabanan yaitu untuk meningkatkan kinerja karyawan agar tetap mampu bersaing di industri otomotif dan PT. Sejahtera Indobali Trada Cabang Tabanan juga melakukan usaha untuk dapat merekrut sumber daya manusia yang berkualitas agar mampu memberikan pelayanan yang memuaskan kepada konsumen.

PT. Sejahtera Indobali Trada Cabang Tabanan tentu tidak terlepas dari berbagai masalah, terutama masalah yang ada hubungannya dengan kinerja karyawan. Newstrom \& Davis (2007:107) menyatakan bahwa karyawan yang motivasinya rendah cenderung melalaikan pekerjaan salah satunya dalam bentuk ketidakhadiran yang tinggi dan juga dapat dilihat dari kinerja karyawannya yang rendah. Tingkat absensi karyawan PT. Sejahtera Indobali Trada Cabang Tabanan dapat dilihat pada Tabel 1. 
Tabel 1.

Tingkat absensi karyawan PT. Sejahtera Indobali Trada Cabang Tabanan 2017

\begin{tabular}{|c|c|c|c|c|c|c|}
\hline No & Bulan & $\begin{array}{c}\text { Hari } \\
\text { Kerja }\end{array}$ & $\begin{array}{c}\text { Jumlah } \\
\text { Karyawan } \\
\text { (Orang) }\end{array}$ & $\begin{array}{c}\text { Jumlah } \\
\text { Hari Kerja } \\
\text { Seharusnya }\end{array}$ & $\begin{array}{c}\text { Absensi } \\
\text { (Hari) }\end{array}$ & $\begin{array}{c}\text { Persentanse } \\
\text { Absensi } \\
\text { Pegawai } \\
\text { (persen) }\end{array}$ \\
\hline 1 & 2 & 3 & 4 & $5=3 \times 4$ & 6 & $\begin{array}{c}7= \\
6 / 5 \times 100 \text { persen }\end{array}$ \\
\hline 1 & Januari & 31 & 54 & 1674 & 54 & 3.23 \\
\hline 2 & Februari & 28 & 54 & 1512 & 46 & 3.04 \\
\hline 3 & Maret & 31 & 54 & 1674 & 55 & 3.29 \\
\hline 4 & April & 30 & 54 & 1620 & 57 & 3.52 \\
\hline 5 & Mei & 31 & 54 & 1674 & 52 & 3.11 \\
\hline 6 & Juni & 30 & 54 & 1620 & 50 & 3.09 \\
\hline 7 & Juli & 31 & 54 & 1674 & 56 & 3.35 \\
\hline 8 & Agustus & 31 & 54 & 1674 & 53 & 3.17 \\
\hline 9 & September & 30 & 54 & 1620 & 50 & 3.09 \\
\hline 10 & Oktober & 31 & 54 & 1674 & 52 & 3.11 \\
\hline 11 & November & 30 & 54 & 1620 & 54 & 3.33 \\
\hline 12 & Desember & 31 & 54 & 1674 & 51 & 3.05 \\
\hline \multicolumn{4}{|c|}{ Jumlah } & 19710 & 920 & 38.35 \\
\hline \multicolumn{4}{|c|}{ Rata-Rata } & 1642.50 & 76.67 & 3.20 \\
\hline
\end{tabular}

Sumber: Data diolah, 2017

Tabel 1. menunjukkan bahwa persentase karyawan setiap bulannya mencapai diatas 3 persen. Tingkat absensi terendah terjadi pada bulan Februari yaitu sebesar 3,04 persen sedangkan pada bulan April merupakan tingkat absensi tertinggi yaitu hingga 3,52 persen. Dapat disimpulkan bahwa, rata-rata tingkat absensi karyawan tergolong tinggi karena berada diatas 3 persen. Utama et al. 2001:93) menyatakan bahwa rata-rata tingkat absensi antara 2-3 persen perbulan masih dianggap baik, jika tingkat absensi $>3-10$ persen maka dianggap tidak wajar.

Berdasarkan rata-rata absensi karyawan, tingkat absensi karyawan PT. Sejahtera Indobali Trada Cabang Tabanan termasuk dalam kategori kurang baik, hal tersebut dikarenakan rata-rata persentase absensi karyawan berada diatas 3 persen. Oleh karena itu perusahaan harus lebih memperhatikan karyawannya, sebab absensi merupakan salah satu cara untuk menilai kinerja karyawan. Dengan mematuhi peraturan-peraturan kerja perusahaan, karyawan akan dapat bersaing dengan karyawan lainnya dan dapat termotivasi untuk jenjang karir yang lebih tinggi, sehingga dapat menghasilkan kinerja yang maksimal.

Berdasarkan hasil wawancara terhadap beberapa karyawan dari PT Sejahtera Indobali Trada Cabang Tabanan mengenai indikasi kinerja karyawan. Faktor-faktor seperti pengembangan karir dan motivasi kerja memiliki peran yang sangat penting untuk mendorong karyawan untuk meningkatkan kinerja di PT Sejahtera Indobali Trada Cabang Tabanan. Hal ini dapat dilihat dari keluhan yang muncul dari karyawan mengenai jaminan kesehatan yang kurang sesuai dengan kinerja yang telah dihasilkan oleh karyawan terhadap perusahaan, target 
penjualan mobil yang tinggi serta dukungan yang kurang didapatkan oleh karyawan untuk jenjang karir di perusahaan.

Robbins (2009:629) mengemukakan kinerja karyawan merupakan sebuah fungsi interaksi kemampuan, motivasi, dan peluang untuk berkinerja. Wirawan (2009:5) mengemukakan bahwa kinerja merupakan keluaran yang dihasilkan oleh fungsi-fungsi atau indikator-indikator suatu pekerjaan atau suatu profesi dalam waktu tertentu.

Hasibuan (2009:121) menyatakan bahwa kinerja merupakan perwujudan kerja yang dilakukan oleh karyawan yang biasanya dipakai sebagai dasar penilaian terhadap karyawan atau organisasi. Kinerja yang baik merupakan langkah untuk tercapainya tujuan organisasi. Sehingga perlu diupayakan usaha untuk meningkatkan kinerja, tetapi hal ini tidak mudah sebab banyak faktor yang mempengaruhi tinggi rendahnya kinerja seseorang.

Mangkunegara (2009:9) menyatakan bahwa kinerja sumber daya manusia adalah pretasi kerja atau hasil kerja (output) baik kualitas maupun kuantitas yang dicapai sumber daya manusia persatuan periode waktu dalam melaksanakan tugas kerjanya sesuai dengan tanggung jawab yang diberikannya. Rivai (2008:131) menyatakan bahwa kinerja merupakan perilaku nyata yang ditampilkan setiap orang sebagai prestasi kerja yang dihasilkan oleh karyawan sesuai dengan perannya dalam perusahaan. Kinerja karyawan merupakan suatu hal yang sangat penting dalam upaya perusahaan untuk mencapai tujuannya. Menurut Prasetyo dkk. (2016) menyatakan bahwa kinerja adalah suatu hasil yang dicapai seseorang dalam melaksanakan tugas-tugas yang didasarkan pada kecakapan, pengalaman, dan kesungguhan serta waktu menurut standar dan kriteria yang telah ditetapkan sebelumnya. Astuti dan Dharmadiaksa (2014) menyatakan bahwa kinerja merupakan tingkat keberhasilan yang dicapai oleh seseorang dalam mengambil pekerjaan dibandingkan dengan standar kerja yang telah ditentukan dan disepakati sebelumnya. Yanti dkk. (2015) menyatakan bahwa Kinerja merupakan hasil kerja secara kualitas dan kuantitas yang dicapai oleh seorang pegawai dalam melaksanakan tugasnya sesuai dengan tanggung jawab yang diberikan kepadanya.

Kinerja karyawan berdasarkan pendapat para ahli dan hasil penelitian terdahulu adalah hasil kerja yang dihasilkan baik dari segi kualitas maupun kuantitas pekerjaannya dan dapat dipertanggungjawabkan sesuai dengan prestasi kerja yang dihasilkan oleh karyawan sesuai dengan peran didalam organisasi atau perusahaan.

Praktek pengembangan karir merupakan suatu pelaksalnaan rencana karir seperti yang diungkapkan oleh Handoko (2012:123) bahwa, "Pengembangan karir adalah peningkatan-peningkatan pribadi yang dilakukan seseorang untuk mencapai suatu rencana karir." Menurut Siagian (2010), pengembangan karir adalah perubahan-perubahan pribadi yang dilakukan seseorang untuk mencapai suatu rencana karir.

Pareek dan Rao (2012) berpendapat bahwa pengembangan karir karyawan harus dilihat sebagai investasi, bukan biaya; dan bahwa kinerja yang buruk, kebodohan dan komitmen rendah itu merupakan biaya dalam suatu organisasi. Hal ini menunjukkan bahwa kunci untuk mencapai kinerja yang optimal terletak 
pada memiliki karyawan yang bersedia bekerja, dikelola dengan baik, baik memimpin, baik termotivasi dan selalu re-skilling. Pengembangan karir sangat penting untuk karyawan dan organisasi. Hal ini karena ada interaksi antara organisasi dan pengembangan organisasi melalui karir karyawan (Armstrong, 2001). Sebuah sistem pengembangan karir yang dirancang dengan baik memungkinkan organisasi untuk memanfaatkan asetnya untuk kepegawaian dan promosi dengan menyesuaikan keterampilan, pengalaman, dan aspirasi karyawan dengan kebutuhan organisasi. Selain itu, memungkinkan manajemen untuk membuat keputusan kompensasi dan perencanaan untuk menarik, mempertahankan dan memotivasi karyawan, sehingga tenaga kerja lebih terlibat dan produktif (Kapel \& Shepherd, 2004). Menurut Nawawi (2005:289) pengembangan karir adalah suatu rangkaian (urutan) posisi atau jabatan yang ditempati sesorang selama masa kehidupan tertentu. Pengembangan karir meliputi manajemen karir dan perencanaan karir. Perencanaan karir adalah proses yang dilalui oleh individu karyawan untuk mengidentifikasikan dan mengambil langkah-langkah untuk mencapai tujuan karirnya. Menurut Lakoy (2013) menyatakan bahwa Pengembangan karir adalah suatu kondisi yang menunjukkan adanya peningkatan-peningkatan status seseorang dalam suatu organisasi. Simamora (2017) menyatakan bahwa pengembangan karir merupakan suatu kondisi yang menunjukkan adanya peningkaatan- peningkatan status seseorang dalam organisasi dalam jalur karir yang telah ditetapkan dalam organisasi yang bersangkutan di Pegawai Negeri Sipil pembinaan karir dan penilaian sistem prestasi kerja dan sistem karir pada umumnya melalui kenaikan pangkat, mutasi jabatan serta pengangkatan dalam jabatan.

Pengembangan karir berdasarkan pendapat para ahli dan hasil penelitian terdahulu adalah suatu tingkatan atau jabatan yang ditempati selama berada di dalam organisasi. Pengembangan karir harus dilalui dengan penyusunan prasyarat yang harus dimiliki oleh seorang karyawan guna mendukung peningkatan karirnya. Syarat-syarat itu sifatnya saling mendukung, dalam arti setiap peningkatan karir harus melalui beberapa criteria seperti prestasi, bobot pekerjaan, adanya lowongan, efisiensi dan lainnya.

Marwansyah (2012:224) mengemukakan bahwa sarana pengembangan karier meliputi keterampilan, pendidikan dan pengalaman serta teknik- teknik modifikasi dan perbaikan perilaku, yang memberikan nilai tambah sehingga memungkinkan seseorang untuk bekerja lebih baik. Metode yang lazim digunakan adalah penyuluhan karier, penyediaan informasi tentang perusahaan atau organisasi, sistem penilaian kinerja dan lokakarya. Pihak perusahaan sering mengadakan program-program pelatihan dan pengembangan bagi karyawan untuk mengarahkan pengembangan karir agar menguntungkan perusahaan dan karyawan.

Perusahaan juga perlu mengusahakan dukungan manajemen, memberikan umpan balik kepada karyawan dan membangun suatu lingkungan kerja yang baik untuk meningkatkan kemampuan dan keinginan karyawan dalam melaksanakan pengembangan karir. Program- program pelatihan dan pengembangan yang dilakukan perusahaan dapat efektif dan efisien sehingga tidak menimbulkan kejenuhan dalam pekerjaan. Mahmoda (2005:18) menyatakan bahwa, dalam 
pekerjaan diperlukan adanya suatu pengembangan karir yang meliputi: mutasi, promosi dan demosi.

Motivasi kerja merupakan ukuran berapa lama seseorang dapat menjaga usaha mereka. Individu yang termotivasi akan menjalankan tugas cukup lama untuk mencapai tujuannya. Maduka (2014) menyatakan bahwa motivasi adalah suatu proses yang berasal dari dalam diri manusia yang memberikan dorongan dalam bentuk aksi dan reaksi. Hasibuan (2009:216) menyatakan bahwa motivasi kerja merupakan suatu cara bagaimana mendorong gairah kerja bawahan agar mereka mau bekerja keras dengan memberikan semua kemampuan dan keterampilannya untuk mengwujudkan tujuan perusahaan.

Zameer et al. (2014) menyatakan pada dasarnya kata motivasi berasal dari kata "motif". Motif adalah kebutuhan, keinginan, dan keinginan dari orang-orang, sehingga motivasi karyawan berarti proses organisasi untuk mendorong karyawan dengan bentuk imbalan, bonus dan lainnya untuk mencapai tujuan organisasi. Simamora (2009:456) menyatakan bahwa motivasi kerja (motivation) adalah dorongan psikologis yang mengarahkan seseorang menuju sebuah tujuan. Uzonna (2013) menyatakan motivasi adalah kombinasi dari kebutuhan, penggerak dan insentif. Motivasi kerja didefinisikan sebagai proses yang dimulai dengan defisiensi fisiologis atau psikologis atau kebutuhan yang mengaktifkan perilaku yang ditujukan untuk tujuan atau insentif. Muogbo (2013) menyatakan motivasi kerja berasal dari kata "memotivasi", berarti langkah, dorongan atau pengaruh untuk melanjutkan sesuatu dalam rangka memenuhi keinginan. Usman (2013:275) menyatakan bahwa motivasi kerja merupakan alat yang digunakan agar bawahan mau bekerja keras dan bekerja cerdas sesuai dengan yang diharapkan. Wibowo (2014:323) menyatakan bahwa motivasi kerja merupakan dorongan terhadap serangkaian proses prilaku manusia pada pencapaian tujuan, sedangkan elemen yang terkandung dalam motivasi meliputi unsur membangkitkan, mengarahkan, menjaga, menunjukkan intensitas, bersifat terusmenerus dan adanya tujuan.

Motivasi kerja berdasarkan pendapat para ahli dan hasil penelitian terdahulu adalah sebuah rangsangan yang membuat seorang individu melakukan pekerjaan lebih giat dan antusias untuk mencapai hasil yang lebih baik dari sebelumnya. Dari sisi lain, motivasi dianggap sebagai usaha positif dimana mampu menggerakkan, mengerahkan dan mengarahkan sumber daya manusia agar secara produktif berhasil mewujudkan dan mencapai tujuan yang diinginkan.

Penelitian yang dilakukan oleh Hennekam (2016) mengemukakan pengembangan karir memiliki pengaruh positif yang signifikan terhadap motivasi kerja karyawan. Hasil penelitian yang dilakukan oleh Sungkono (2013) menyatakan bahwa pengembangan karir berpengaruh positif dan signifikan terhadap motivasi kerja karyawan PT. Excel Utama Indonesia Karawang. Penelitian yang dilakukan oleh Bapiri \& Alizad (2015) menyatakan bahwa career development berpengaruh positif dan signifikan terhadap motivasi kerja karyawan di Sepah Bank. Kurniawan et al. (2017) menyatakan menyatakan bahwa pengembangan karir berpengaruh positif dan signifikan terhadap motivasi kerja karyawan PT. Bank Syariah Mandiri Cabang Banda Aceh. Dik \& Steger (2008) mengemukakan pengembangan karir memiliki pengaruh positif yang signifikan 
terhadap motivasi kerja karyawan. Sakti (2013) menyatakan bahwa pengembangan karir berpengaruh positif dan signifikan terhadap motivasi kerja karyawan di Toko Buku Gramedia Basuki Rachmat Malang. Dewi \& Utama (2016) menyatakan pengembangan karir berpengaruh positif dan signifikan terhadap motivasi kerja pada Karya Mas Art Gallery. Berdasarkan uraian di atas, maka dapat dirumuskan hipotesis sebagai berikut.

$\mathrm{H}_{1}$ : Pengembangan karir berpengaruh positif dan signifikan terhadap motivasi kerja karyawan.

Penelitian yang dilakukan oleh Bianca et al. (2014) menyatakan bahwa pengembangan karir karyawan secara langsung memberikan pengaruh positif terhadap kinerja karyawan, yang artinya kinerja karyawan secara tidak langsung juga mempengaruhi efektivitas perusahaan. Hasil penelitian yang dilakukan oleh Oduma \& Were (2014) mengemukakan bahwa kemajuan karir berpengaruh secara positif dan signifikan terhadap kinerja karyawan di Kenyatta University. Dewi \& Utama (2016) menyatakan pengembangan karir berpengaruh positif dan signifikan terhadap kinerja karyawan pada Karya Mas Art Gallery. Penelitian yang dilakukan oleh Hameed \& Waheed (2011) menyatakan bahwa pengembangan karyawan sangat mempengaruhi kinerja organisasi untuk kefektifan organisasi itu sendiri. Patrick \& Kumar (2011) mengemukakan dalam penelitiannya bahwa pengembangan karir karyawan berpengaruh positif dan signifikan di sebuah organisasi informasi dan teknologi di India. Satria et al. (2015) mengemukakan bahwa pengembangan karir yang dimiliki oleh PT. Nyonya Meneer Semarang berpengaruh positif terhadap kinerja karyawan. Sarifah et al. (2016) menyatakan dalam penelitiannya pengembangan karir secara bersama-sama atau simultan berpengaruh signifikan terhadap kinerja karyawan di PT Nusantara Tour Semarang. Berdasarkan uraian di atas, dapat dirumuskan hipotesis sebagai berikut.

$\mathrm{H}_{2}$ : Pengembangan karir berpengaruh positif dan signifikan terhadap kinerja karyawan.

Penelitian yang dilakukan oleh Riyanti \& Sudibya (2013) menyatakan motivasi berpengaruh positif dan signifikan terhadap kinerja karyawan pada Rumah Sakit Umum Dharma Usadha. Nupur \& Barti (2012) mengemukakan bahwa motivasi kerja karyawan memiliki dampak langsung pada produktivitas dan pertumbuhan. Peningkatan kinerja pekerjaan karyawan akan menambah nilai organisasi itu sendiri dan produktivitas karyawan. Muogbo (2013) menyatakan bahwa pemberian motivasi bagi para pekerja dalam suatu organisasi dapat berpengaruh signifikan terhadap kinerja para pekerja di Anambra State Nigeria. Hasil penelitian yang dilakukan oleh Zameer et al. (2014) menyatakan bahwa motivasi secara signifikan dmempengaruhi kinerja karyawan di industri minuman Pakistan. Prabasari \& Netra (2013) dalam penelitiannya mengemukakan bahwa motivasi memiliki pengaruh yang positif dan signifikan terhadap kinerja karyawan di PT. PLN (Persero) Distribusi Bali. Azar \& Shafighi (2013) menyatakan motivasi berpengaruh positif dan signifikan terhadap kinerja karyawan. Dewi \& Utama (2016) menyatakan motivasi kerja berpengaruh positif dan signifikan terhadap kinerja karyawan pada Karya Mas Art Gallery. Uzonna (2013) menyatakan motivasi kerja berpengaruh positif dan signifikan terhadap 
kinerja karyawan di Studi Kasus Kredit West Bank Cyprus. Murty \& Hudiwinarsih (2012) menyatakan motivasi kerja berpengaruh positif dan signifikan terhadap kinerja karyawan. Penelitian yang dilakukan oleh Arifin (2015) mengemukakan bahwa motivasi berpengaruh positif dan signifikan terhadap kinerja karyawan. Berdasarkan uraian tersebut, maka dapat dirumuskan hipotesis sebagai berikut.

$\mathrm{H}_{3}$ : Motivasi kerja berpengaruh positif dan signifikan terhadap kinerja karyawan.

Penelitian yang dilakukan oleh Dewi \& Utama (2016) menyatakan bahwa pengembangan karir dan motivasi berpengaruh positif dan signifikan terhadap kinerja karyawan. Umar (2015) mengemukakan bahwa motivasi kerja memediasi pengaruh pengembangan karir terhadap kinerja karyawan. Novialumi (2018) menyatakan bahwa pengembangan karir dan motivasi berpengaruh positif dan signifikan terhadap kinerja karyawan. Berdasarkan uraian tersebut, dapat dirumuskan hipotesis sebagai berikut.

$\mathrm{H}_{4}$ : Motivasi kerja berpengaruh positif dan signifikan dalam memediasi hubungan antara pengembangan karir terhadap kinerja karyawan.

\section{METODE PENELITIAN}

Lokasi penelitian ini dilakukan di PT. Sejahtera Indobali Trada Cabang Tabanan yang beralamat di Jl. Ir. Soekarno, Banjar Anyar, Kediri, Tabanan. Lokasi ini dipilih karena terdapat masalah dengan pengembangan karir, motivasi kerja dan kinerja karyawan. Obyek dalam penelitian adalah pengembangan karir, motivasi kerja pada kinerja karyawan di PT. Sejahtera Indobali Trada Cabang Tabanan.

Populasi dalam penelitian ini adalah seluruh karyawan PT. Sejahtera Indobali Trada Cabang Tabanan dalam penelitian ini adalah 54 responden dari karyawan.

Metode penentuan sampel yang digunakan adalah sampel jenuh, dimana seluruh anggota populasi digunakan sebagai sampel. Sampel dalam penelitian ini adalah seluruh karyawan PT Sejahtera Indobali Trada Cabang Tabanan yang berjumlah 54 orang. Berikut merupakan jumlah karyawan yang ada di PT Sejahtera Indobali Trada Cabang Tabanan pada Tabel 2.

Tabel 2.

Jumlah Karyawan di PT Sejahtera Indobali Trada Cabang Tabanan

\begin{tabular}{ccc}
\hline No & Jabatan & Banyak Karyawan (orang) \\
\hline 1 & Operations & 6 \\
2 & Sales & 27 \\
3 & Service & 19 \\
4 & Spare Parts & 2 \\
\hline & Total & $\mathbf{5 4}$ \\
\hline
\end{tabular}

Sumber: Data diolah, 2018

Tabel 2. menunjukkan bahwa jumlah karyawan di PT Sejahtera Indobali Trada Cabang Tabanan sebanyak 54 orang. Dari jumlah karyawan sebanyak 54 orang terdapat 4 jabatan yang ada di PT Sejahtera Indobali Trada Cabang 
Tabanan yaitu Operations sebanyak 6 orang, Sales sebanyak 27 orang, Service sebanyak 19 orang dan Spare Parts sebanyak 2 orang.

Teknik analisis data dalam penelitian ini menggunakan teknik analisis jalur (path analysis).

Persamaan Sub-struktural 1

Persamaan Sub-struktural 2

$$
\mathrm{M}=\beta 1 \mathrm{X}+\mathrm{e}
$$

$$
\begin{aligned}
& \mathrm{Y}=\beta 1 \mathrm{X}+\beta 2 \mathrm{Y} 1+\mathrm{e} \\
& \text { Keterangan: } \\
& \mathrm{Y} \quad=\text { kinerja karyawan } \\
& \mathrm{X}=\text { pengembangan karir } \\
& \mathrm{M} \quad=\text { motivasi kerja } \\
& \beta 1, \beta 2=\text { koefisien regresi variabel } \\
& \text { e } \quad=\text { error }
\end{aligned}
$$

\begin{tabular}{|c|c|c|c|c|c|}
\hline \multirow[t]{2}{*}{ Variabel } & \multicolumn{2}{|c|}{$\begin{array}{l}\text { Unstandardized } \\
\text { Coefficients }\end{array}$} & \multirow{2}{*}{$\begin{array}{c}\text { Standardized } \\
\text { Coefficients } \\
\text { Beta }\end{array}$} & \multirow[t]{2}{*}{$\begin{array}{c}\mathrm{t} \\
\text { hitung }\end{array}$} & \multirow[t]{2}{*}{$\underset{t}{\text { Sig. uji }}$} \\
\hline & B & Std. Error & & & \\
\hline (Constant) & 0,750 & 1,847 & & 0,406 & 0,686 \\
\hline $\begin{array}{l}\text { Pengembangan Karir } \\
\text { (X) }\end{array}$ & 0,424 & 0,050 & 0,759 & 8,416 & 0,000 \\
\hline R Square & 0,577 & & & & \\
\hline F Statistik & 70,836 & & & & \\
\hline Signifikansi Uji F & 0,000 & & & & \\
\hline
\end{tabular}

\section{HASIL DAN PEMBAHASAN}

Perhitungan koefisien path dilakukan dengan analisis regresi melalui software SPSS 25.0 for Windows, diperoleh hasil yang ditunjukan pada Tabel 3 sebagai berikut.

Tabel 3.

Hasil Analisis Jalur 1

Tabel 3. menunjukkan bahwa hasil analisis jalur substruktur 1, maka dapat dibuat persamaan struktural sebagai berikut:

$$
\begin{aligned}
& M=\alpha+\beta_{1} X+e_{1} \ldots \ldots \ldots \ldots \ldots \\
& M=0,750+0,759 X+0,050
\end{aligned}
$$

Nilai koefisien regresi variabel orientasi pasar bernilai positif dengan nilai signifikansi uji t kurang dari 0,05. Hal ini menunjukkan bahwa variabel pengembangan karir memiliki pengaruh positif yang signifikan terhadap variabel motivasi. Besarnya pengaruh variabel bebas terhadap variabel terikat yang ditunjukkan oleh nilai determinasi total (R Square) sebesar 0,577 mempunyai arti bahwa sebesar 57,7 persen variasi motivasi dipengaruhi oleh variasi pengembangan karir, sedangkan sisanya sebesar 42,3persen dijelaskan oleh faktor 
lain yang tidak dimasukkan ke dalam model. Diperoleh hasil yang ditunjukan pada Tabel 4 sebagai berikut.

Tabel 4.

Hasil Analisis Jalur 2

\begin{tabular}{lccccc}
\hline \multicolumn{1}{c}{ Variabel } & \multicolumn{2}{c}{$\begin{array}{c}\text { Unstandardized } \\
\text { Coefficients }\end{array}$} & $\begin{array}{c}\text { Standardized } \\
\text { Coefficients } \\
\text { Beta }\end{array}$ & $\begin{array}{c}\mathbf{t} \\
\text { hitung }\end{array}$ & $\begin{array}{c}\text { Sig. uji } \\
\mathbf{t}\end{array}$ \\
& $\mathbf{B}$ & Std. Error & & & \\
\hline (Constant) & 3,577 & 2,601 & & 1,375 & 0,175 \\
Pengembangan Karir & 0,610 & 0,109 & 0,582 & 5,600 & 0,000 \\
(X) & & & & & \\
Motivasi (M) & 0,653 & 0,195 & 0,348 & 3,348 & 0,002 \\
R Square & 0,767 & & & & \\
F Statistik & 83,915 & & & & \\
Signifikansi Uji F & 0,000 & & & &
\end{tabular}

Tabel 4. menunjukkan bahwa hasil analisis jalur substruktur 2, maka dapat dibuat persamaan struktural sebagai berikut:

$$
\mathrm{Y}=3,577+0,582 \mathrm{X}+0,348 \mathrm{M}+0,195
$$

Nilai koefisien regresi masing-masing variabel bebas bernilai positif dengan nilai signifikansi uji t kurang dari 0,050. Hal ini menunjukkan bahwa semua variabel bebas memiliki pengaruh positif yang signifikan terhadap variabel terikat. Besarnya pengaruh variabel bebas terhadap variabel terikat yang ditunjukkan oleh nilai determinasi total ( $\mathrm{R}$ Square) sebesar 0,767 mempunyai arti bahwa sebesar 76,7persen variasi kinerja karyawan dipengaruhi oleh variasi pengembangan karir dan motivasi, sedangkan sisanya sebesar 23,3persen dijelaskan oleh faktor lain yang tidak dimasukkan ke dalam model.

Berdasarkan model substruktur 1 dan substruktur 2, maka dapat disusun model diagram jalur akhir. Sebelum menyusun model diagram jalur akhir, terlebih dahulu dihitung nilai standar error sebagai berikut :

$$
\begin{aligned}
& \mathrm{Pe}_{\mathrm{i}}=\sqrt{1-\mathrm{R}_{\mathrm{i}}{ }^{2}} \ldots \ldots \ldots \ldots \ldots \ldots \ldots \ldots \ldots \ldots \ldots \ldots \ldots \\
& \mathrm{Pe}_{1}=\sqrt{1-R_{1}{ }^{2}}=\sqrt{1-0,577}=0,650 \\
& \mathrm{Pe}_{2}=\sqrt{1-R_{2}{ }^{2}}=\sqrt{1-0,767}=0,482
\end{aligned}
$$

Berdasarkan perhitungan pengaruh error (Pei), didapatkan hasil pengaruh error $\left(\mathrm{Pe}_{1}\right)$ sebesar 0,650 dan pengaruh error $\left(\mathrm{Pe}_{2}\right)$ sebesar 0,482. Hasil koefisien determinasi total adalah sebagai berikut:

$$
\begin{aligned}
\mathrm{R}^{2}{ }_{\mathrm{m}} & =1-\left(\mathrm{Pe}_{1}\right)^{2}\left(\mathrm{Pe}_{2}\right)^{2} \\
& =1-(0,650)^{2}(0,482)^{2} \\
& =1-(0,423)(0,232) \\
& =1-0,098=0,902
\end{aligned}
$$

Nilai determinasi total sebesar 0,902 mempunyai arti bahwa sebesar 90,2persen variasi kinerja karyawan dipengaruhi oleh variasi pengembangan karir 
dan motivasi, sedangkan sisanya sebesar 8,8persen djelaskan oleh faktor lain yang tidak dimasukkan ke dalam model.

Tabel 5.

Pengaruh Langsung dan Pengaruh Tidak Langsung serta Pengaruh Total Pengembangan Karir (X), Motivasi (M), dan Kinerja Karyawan (Y)

\begin{tabular}{cccc}
\hline $\begin{array}{c}\text { Pengaruh } \\
\text { Variabel }\end{array}$ & $\begin{array}{c}\text { Pengaruh } \\
\text { Langsung }\end{array}$ & $\begin{array}{c}\text { Pengaruh Tidak Langsung } \\
\text { Melalui Kinerja Karyawan } \\
(\mathbf{Y 1})(\boldsymbol{\beta 1} \mathbf{x} \boldsymbol{\beta})\end{array}$ & Pengaruh Total \\
\hline $\mathrm{X} \rightarrow \mathrm{M}$ & 0,759 & - & 0,759 \\
$\mathrm{X} \rightarrow \mathrm{Y}$ & 0,582 & 0,264 & 0,846 \\
$\mathrm{M} \rightarrow \mathrm{Y}$ & 0,348 & - & 0,348 \\
\hline \multicolumn{2}{l}{ Sumber: Data diolah, 2018} & &
\end{tabular}

Tabel 5. menunjukkan bahwa pengaruh langsung pengembangan karir terhadap motivasi adalah sebesar 0,759. Pengaruh langsung variabel pengembangan karir terhadap kinerja karyawan sebesar 0,582. Pengaruh langsung variabel motivasi terhadap kinerja karyawan sebesar 0,348. Hal ini berarti bahwa variabel kinerja karyawan lebih besar dipengaruhi oleh motivasi dari pengembangan karir. Sedangkan pengaruh tidak langsung variabel pengembangan karir terhadap kinerja karyawan melalui motivasi sebesar 0,264. Jadi pengaruh total variabel pengembangan karir terhadap kinerja karyawan melalui motivasi adalah sebesar 0,846 Jadi dapat disimpulkan bahwa lebih besar total pengaruh pengembangan karir terhadap kinerja karyawan yang melalui motivasi, daripada pengaruh langsung pengembangan karir terhadap kinerja karyawan tanpa melalui motivasi.

Uji sobel digunakan untuk menguji kekuatan pengaruh tidak langsung pengembangan karir $(\mathrm{X})$ terhadap kinerja karyawan $(\mathrm{Y})$ melalui motivasi kerja (M). Pengaruh tidak langsung pengembangan karir (X) terhadap kinerja karyawan (Y) melalui motivasi kerja (M).

Untuk menguji signifikansi Standard error tidak langsung (indirect effect) atau Sab, dihitung dengan rumus sebagai berikut:

$$
\begin{aligned}
& S_{a b}=\sqrt{(0,348)^{2}(0,195)^{2}+(0,759)^{2}(0,050)^{2}+(0,195)^{2}(0,050)^{2}} \\
& S_{a b}=0,0784
\end{aligned}
$$

Keterangan:

$$
\begin{array}{ll}
0,050 & =\text { Standard error koefisien } \mathrm{a} \\
0,195 & =\text { Standard error koefisien } \mathrm{b} \\
0,0784 & =\text { Besarnya standard error tidak langsung } \\
0,759 & =\text { Koefisien jalur X terhadap } \mathrm{M} \\
0,348 & =\text { Koefisien jalur M terhadap } \mathrm{Y}
\end{array}
$$

Untuk menguji signifikansi pengaruh tidak langsung maka menghitung nilai $\mathrm{z}$ dari koefisien $\mathrm{ab}$ dengan rumus sebagai berikut.

$$
Z=\frac{a b}{S a b}
$$




$$
\begin{aligned}
& Z=\frac{(0,759)(0,348)}{0,0784} \\
& Z=3,370
\end{aligned}
$$

Oleh karena $Z$ hitung sebesar 3,370 > 1,96 (dengan tingkat kepercayaan sebesar 95 persen). Hal ini menunjukkan bahwa motivasi (M) merupakan variabel yang memediasi pengembangan karir (X) terhadap kinerja karyawan (Y) atau dengan kata lain pengembangan karir berpengaruh secara tidak langsung terhadap kinerja karyawan melalui motivasi.

Pengujian hipotesis mediasi dilakukan dengan metode VAF. VAF menjadi ukuran seberapa besar variabel pemediasi mampu menyerap pengaruh langsung yang sebelumnya signifikan dari model tanpa pemediasi. Untuk model VAF dapat dihitung dengan $(\mathrm{b} \times \mathrm{c}) /(\mathrm{a}+\mathrm{b} \times \mathrm{c})$. Apabila nilai VAF di atas 80 persen, maka menunjukkan peran Y1 sebagai pemediasi penuh (full mediation). Selanjutnya apabila nilai VAF di antara 20 persen hingga 80 persen, maka dapat dikategorikan sebagai pemediasi parsial (partial mediation). Namun, apabila nilai VAF kurang dari 20 persen, maka dapat dijelaskan bahwa hampir tidak ada efek mediasi.

$$
\begin{aligned}
& \mathrm{VAF}=(0,759 \times 0,348) /(0,759+0,348 \times 0,846) \\
& \quad=0,264 / 0,937 \\
& =0,282 \text { atau } 28,2 \text { persen. }
\end{aligned}
$$

Karena nilai VAF (28,2 persen) lebih dari 20 persen dan tidak melebihi 80 persen, maka dapat dijelaskan bahwa ada efek mediasi atau dengan kata lain motivasi dapat dikategorikan sebagai pemediasi parsial (partial mediation).

Pengaruh Pengembangan Karir Terhadap Motivasi Kerja diperoleh nilai Signifikansi 0,000 dengan nilai koefisien beta sebesar 0,759. Nilai Signifikansi $0,000<0,05$ hasil ini mempunyai arti pengembangan karir berpengaruh positif dan signifikan terhadap motivasi kerja. Artinya pengembangan karir yang sesuai dengan keinginan karyawan membuat motivasi karyawan di PT Sejahtera Indobali Trada Cabang Tabanan menjadi lebih termotivasi. Hasil penelitian ini sesuai dengan hipotesis yang diajukan dan juga sesuai dengan Hennekam (2016) mengemukakan pengembangan karir memiliki pengaruh positif yang signifikan terhadap motivasi kerja karyawan. Hasil penelitian yang dilakukan oleh Sungkono (2013) menyatakan bahwa pengembangan karir berpengaruh positif dan signifikan terhadap motivasi kerja karyawan PT. Excel Utama Indonesia Karawang. Penelitian yang dilakukan oleh Bapiri \& Alizad (2015) menyatakan bahwa career development berpengaruh positif dan signifikan terhadap motivasi kerja karyawan di Sepah Bank. Kurniawan et al. (2017) menyatakan menyatakan bahwa pengembangan karir berpengaruh positif dan signifikan terhadap motivasi kerja karyawan PT. Bank Syariah Mandiri Cabang Banda Aceh. Sakti (2013) menyatakan bahwa pengembangan karir berpengaruh positif dan signifikan terhadap motivasi kerja karyawan di Toko Buku Gramedia Basuki Rachmat Malang.

Pengaruh Pengembangan Karir Terhadap Kinerja Karyawan diperoleh nilai Signifikansi 0,000 dengan nilai koefisien beta sebesar 0,582. Nilai Signifikansi $0,000<0,05$ hasil ini mempunyai arti pengembangan karir berpengaruh positif dan signifikan terhadap kinerja karyawan. Artinya pengembangan karir yang 
sesuai dengan keinginan karyawan membuat kinerja karyawan di PT Sejahtera Indobali Trada Cabang Tabanan lebih maksimal. Hasil penelitian ini sesuai dengan hipotesis yang diajukan dan juga sesuai dengan Bianca et al. (2014) menyatakan bahwa pengembangan karir karyawan secara langsung memberikan pengaruh positif terhadap kinerja karyawan, yang artinya kinerja karyawan secara tidak langsung juga mempengaruhi efektivitas perusahaan. Hasil penelitian yang dilakukan oleh Oduma \& Were (2014) mengemukakan bahwa kemajuan karir berpengaruh secara positif dan signifikan terhadap kinerja karyawan di Kenyatta University. Dewi \& Utama (2016) menyatakan pengembangan karir berpengaruh positif dan signifikan terhadap kinerja karyawan pada Karya Mas Art Gallery. (Satria et al., 2015) mengemukakan bahwa pengembangan karir yang dimiliki oleh PT. Nyonya Meneer Semarang berpengaruh positif terhadap kinerja karyawan. Sarifah et al. (2016) menyatakan dalam penelitiannya pengembangan karir secara bersama-sama atau simultan berpengaruh signifikan terhadap kinerja karyawan di PT Nusantara Tour Semarang.

Pengaruh Motivasi Kerja Terhadap Kinerja Karyawan diperoleh nilai Signifikansi 0,000 dengan nilai koefisien beta sebesar 0,348. Nilai Signifikansi $0,002<0,05$ hasil ini mempunyai arti motivasi kerja berpengaruh positif dan signifikan terhadap kinerja karyawan. Artinya motivasi kerja yang baik membuat kinerja karyawan di PT Sejahtera Indobali Trada Cabang Tabanan lebih maksimal. Hasil penelitian ini sesuai dengan hipotesis yang diajukan dan juga sesuai dengan Riyanti \& Sudibya (2013) menyatakan motivasi berpengaruh positif dan signifikan terhadap kinerja karyawan pada Rumah Sakit Umum Dharma Usadha. Muogbo (2013) menyatakan bahwa pemberian motivasi bagi para pekerja dalam suatu organisasi dapat berpengaruh signifikan terhadap kinerja para pekerja di Anambra State Nigeria. Hasil penelitian yang dilakukan oleh Zameer et al. (2014) menyatakan bahwa motivasi secara signifikan dmempengaruhi kinerja karyawan di industri minuman Pakistan. Prabasari \& Netra (2013) dalam penelitiannya mengemukakan bahwa motivasi memiliki pengaruh yang positif dan signifikan terhadap kinerja karyawan di PT. PLN (Persero) Distribusi Bali. Azar \& Shafighi (2013) menyatakan motivasi berpengaruh positif dan signifikan terhadap kinerja karyawan.

Peran Motivasi Kerja Dalam Memediasi Pengaruh Pengembangan Karir Terhadap Kinerja Karyawan menunjukkan bahwa pengaruh langsung pengembangan karir terhadap motivasi adalah sebesar 0,759. Pengaruh langsung variabel pengembangan karir terhadap kinerja karyawan sebesar 0,582. Pengaruh langsung variabel motivasi terhadap kinerja karyawan sebesar 0,348. Hal ini berarti bahwa variabel kinerja karyawan lebih besar dipengaruhi oleh motivasi dari pengembangan karir. Sedangkan pengaruh tidak langsung variabel pengembangan karir terhadap kinerja karyawan melalui motivasi sebesar 0,264. Jadi pengaruh total variabel pengembangan karir terhadap kinerja karyawan melalui motivasi adalah sebesar 0,846 Jadi dapat disimpulkan bahwa lebih besar total pengaruh pengembangan karir terhadap kinerja karyawan yang melalui motivasi, daripada pengaruh langsung pengembangan karir terhadap kinerja karyawan tanpa melalui variabel motivasi. Hasil penelitian ini sesuai dengan hipotesis yang diajukan dan juga sesuai dengan Dewi \& Utama (2016) 
menyatakan bahwa pengembangan karir dan motivasi berpengaruh positif dan signifikan terhadap kinerja karyawan Karya Mas Art Gallery. Umar (2015) mengemukakan bahwa motivasi kerja memediasi pengaruh pengembangan karir terhadap kinerja karyawan. Novialumi (2018) menyatakan bahwa pengembangan karir dan motivasi berpengaruh positif dan signifikan terhadap kinerja karyawan.

Hasil penelitian ini memiliki implikasi teoritis dan praktis. Secara teoritis, hasil penelitian ini menunjukkan bahwa pengembangan karir dan motivasi kerja berpengaruh positif dan signifikan terhadap kinerja karyawan. Dengan demikian, hasil penelitian ini memberi dukungan empiris dan dapat dinyatakan memperkuat hasil-hasil studi terdahulu. Secara praktis, penelitian ini diharapkan dapat memberikan manfaat bagi pemimpin dan karyawan di PT Sejahtera Indobali Trada Cabang Tabanan. Pihak manajemen dan karyawan diharapkan dapat meningkatkan kinerja karyawan dalam perusahaan guna dapat menciptakan hasil kerja yang lebih efektif dan efisien. Berikut merupakan implikasi dari hasil PT Sejahtera Indobali Trada Cabang Tabanan adalah sebagai berikut.

Pengembangan karir adalah suatu tingkatan atau jabatan yang ditempati selama berada di dalam perusahaan. Pengembangan karir yang jelas dalam organisasi akan dapat meningkatkan motivasi kerja karyawan dalam menjalankan pekerjaannya, sehingga menciptakan rasa puas dalam melaksanakan pekerjaannya. Hasil penelitian ini menunjukkan bahwa pengembangan karir berpengaruh terhadap motivasi kerja. Hal ini mengandung implikasi agar kedepannya pimpinan mampu membuat karyawan termotivasi untuk bersaing meningkatkan karir.

Pengembangan karir merupakan pendekatan yang dilakukan perusahaan untuk menjamin orang-orang dalam perusahaan mempunyai kualifikasi, kemampuan, dan pengalaman yang sesuai untuk meningkatkan kinerja dari karyawan. Hasil penelitian ini menunjukkan bahwa pengembangan karir berpengaruh terhadap kinerja karyawan. Hal ini mengandung implikasi agar kedepannya pimpinan mampu membuat karyawan untuk meningkatkan kinerja karyawan sehingga tujuan dari perusahaan dapat tercapai.

Motivasi kerja merupakan sebuah rangsangan yang membuat seorang individu melakukan pekerjaan lebih giat dan antusias untuk mencapai hasil yang lebih baik dari sebelumnya. Hasil penelitian ini menunjukkan bahwa motivasi kerja berpengaruh terhadap kinerja karyawan. Hal ini mengandung implikasi agar kedepannya pimpinan dapat merangsang karyawan untuk meningkatkan kinerja dari karyawan sehingga tujuan dari perusahaan dapat tercapai.

Kinerja karyawan merupakan hasil kerja yang dihasilkan seorang individu baik dari segi kualitas maupun kuantitas pekerjaannya dan dapat dipertanggungjawabkan dengan hasil kerja yang dihasilkan oleh karyawan sesuai jabatan ditempati di perusahaan. Hal ini mengandung implikasi agar kedepannya pemimpin dapat merangsang karyawan untuk meningkatkan kinerja dari karyawan sehingga setiap individu dapat bersaing untuk meningkatkan karir.

Jumlah responden hanya 54 orang karyawan dan hanya dari lingkungan PT Sejahtera Indobali Trada Cabang Tabanan, sehingga hasil penelitian ini hanya dapat diterapkan dilingkungan kerja PT Sejahtera Indobali Trada Cabang Tabanan dan tidak dapat direalisasikan pada lingkungan perusahaan lain. 
Adanya keterbatasan penelitian dengan menggunakan kuesioner yaitu jawaban dari responden terkadang kurang menunjukkan keadaan yang sesungguhnya. Serta pemberian hasil kuesioner yang cukup lama sehingga memperlambat pengolahan data.

Faktor-faktor yang mempengaruhi kinerja karyawan dalam penelitian ini hanya terdiri dari satu variabel mediasi yaitu motivasi kerja, sedangkan masih banyak faktor lain yang mempengaruhi kinerja karyawan.

\section{SIMPULAN}

Pengembangan karir berpengaruh positif dan signfikan terhadap motivasi kerja karyawan. Hal ini menunjukkan bahwa jika pengembangan karir semakin meningkat maka akan dapat meningkatkan pula motivasi kerja karyawan. Pengembangan karir berpengaruh positif dan signfikan terhadap kinerja karyawan. Hal ini menunjukkan bahwa jika pengembangan karir semakin meningkat maka dapat meningkatkan kinerja karyawan.

Motivasi berpengaruh positif dan signifikan terhadap kinerja karyawan. Hal ini menunjukkan bahwa semakin tinggi motivasi kerja karyawan maka dapat meningkatkan kinerja karyawan. Motivasi secara positif dan signifikan memediasi pengaruh pengembangan karir terhadap kinerja karyawan. Hal ini menunjukkan bahwa pengembangan karir memberikan dampak yang signifikan terhadap kinerja karyawan jika di mediasi oleh motivasi, yang berarti bahwa kinerja karyawan sangat tergantung pada tingkat motivasi dari karyawan tersebut dan juga tingkat pengembangan karir karyawan.

PT Sejahtera Indobali Trada Cabang Tabanan sebaiknya dapat lebih menjelaskan mengenai tugas-tugas yang diberikan kepada karyawan, karena ketika karyawan kurang memahami tugas-tugas apa saja yang harus diselesaikan di dalam perusahaan, maka akan membuat pemimpin dari perusahaan tersebut memberikan informasi yang berulang-ulang mengenai tugas-tugas yang harus diselesaikan oleh karyawan di PT Sejahtera Indobali Trada Cabang Tabanan.

PT Sejahtera Indobali Trada Cabang Tabanan sebaiknya dapat lebih memperhatikan mengenai jaminan kesehatan yang diberikan kepada karyawan, ketika karyawan merasa mendapatkan jaminan kesehatan yang tidak sesuai atas kinerja yang dilakukannya membuat kurangnya motivasi dari karyawan untuk menyelesaikan pekerjaan dengan maksimal. Sehingga membuat tingkat absensi yang di PT Sejahtera Indobali Trada Cabang Tabanan menjadi tinggi. Oleh karena itu perusahaan harus memberikan penghargaan seperti bonus jika tingkat absensi karyawan itu rendah. PT Sejahtera Indobali Trada Cabang Tabanan sebaiknya dapat lebih memperhatikan pendidikan yang didapatkan karyawan dalam meningkatkan kemampuan dalam melaksanakan pekerjaan, karena ketika karyawan mendapatkan pendidikan yang sudah sesuai akan membuat karyawan mendapatkan peluang promosi jabatan. Sehingga karyawan dapat melaksanakan pekerjaan dengan hasil maksimal. PT Sejahtera Indobali Trada Cabang Tabanan sebaiknya dapat lebih memperhatikan aspek-aspek yang dinilai rendah oleh karyawan pada kinerja karyawan di PT Sejahtera Indobali Trada Cabang Tabanan yaitu tugas-tugas, jaminan kesehatan, dan pendidikan yang didapatkan karyawan. 
Sehingga karyawan dapat meningkatkan kinerja dan bekerja secara maksimal sesuai dengan yang diharapkan oleh perusahaan.

\section{REFERENSI}

Arifin, H. M. (2015). The Infuence of Competence, Motivation, and Organisational Culture to High School Teacher Job Statisfaction and Performance. International Education Studies, 8(1), 38-45. https://doi.org/10.5539/ies.v8n1p38

Asriningtyas. (2016). Pengaruh Pengembangan Karir Dan Kepuasan Kerja Terhadap Kinerja Karyawan (Studi Kasus Pada Karyawan Pt Inti Sukses Garmindo Tbk Semarang). Universitas Muhamdiyah.

Azar, M., \& Shafighi, A. A. (2013). The Effect of Work Motivation on Employees' Job Performance (Case Study: Employees of Isfahan Islamic Revolution Housing Foundation). International Journal of Academic Research in Business and Social Sciences, 3(9), 432-445. https://doi.org/10.6007/IJARBSS/v3-i9/231

Bapiri, S., \& Alizad, R. . (2015). Evaluation of The Effect of Career Development on Occupational Motivation in Employees of the Sepah Bank in Kermanshah Country. GMP Review, 18(1), 633-642.

Bianca, A., Katili, P. B., \& Anggraeni, S. K. (2014). Pengaruh Motivasi , Pengembangan Karir , dan Kepuasan Kerja Terhadap Kinerja Karyawan Dengan Metode Structural Equation Modelling. Jurnal Teknik Industri, 2(3).

Damayanti, A. P., \& Sumaryati, S. (2013). Pengaruh Kompensasi dan Motivasi Kerja Terhadap Kinerja Karyawan Perusahaan Daerah Air Mineral (PDAM) Surakarta. Jupe UNS, 2(1), 155-168.

Dewi, N. L. P. A. A., \& Utama, I. W. M. (2016). Pengaruh Pengembangan Karir Terhadap Kinerja Karyawan Melalui Mediasi Motivasi Kerja Pada Karya Mas Art Gallery. E-Jurnal Manajemen Unud, 5(9), 5494-5523.

Dik, B. J., \& Steger, M. (2008). Career Development StrivingsAssessing Goals and Motivation in Career Decision-Making and Planning. Journal of Career Development, 35(1), 23-41. https://doi.org/10.1177/0894845308317934

Florence, O. K. (2007). The Effect of Employee Career Development on Performance of Public Primary Schools in Kenya: A Case of Starehe District, Nairobi County. Kenyatta Univesity.

Hameed, A., \& Waheed, A. (2011). Employee Development and Its Affect on Employee Performance A Conceptual Framework. International Journal of Business and Social Science, 2(13), 224-229.

Hennekam, S. (2016). Competencies of older workers and its influence on career success and job satisfaction. Employee Relations, 38(2), 130-146. https://doi.org/10.1108/ER-05-2014-0054 
Kasegar, R. G. (2013). Pengembangan Karir dan Self-Efficacy Terhadap Kinerja Karyawan Pada PT. Matahari Department Store Manado Town Square. Jurnal EMBA, 1(4), 906-916.

Kurniawan, A., Yunus, M., \& Majid, M. S. A. (2017). Pengaruh Kompensasi dan Pengembangan Karir terhadap Motivasi serta Dampaknya pada Kinerja Karyawan PT. Bank Syariah Mandiri Cabang Banda Aceh. Jurnal Manajemen Dan Inovasi, 8(2), 119-133.

Larasati, S., \& Gilang, A. (2014). Pengaruh Motivasi Kerja terhadap Kinerja Karyawan Wilayah Telkom Jabar Barat Utara (Witel Bekasi). Jurnal Manajemen Dan Organisasi, V(3), 200-213.

Muogbo, U. S. (2013). The Impact of Employee Motivation On Organisational Performance (A Study Of Some Selected Firms In Anambra State Nigeria). The International Journal Of Engineering And Science (IJES), 2(7), 70-80.

Murty, W. A., \& Hudiwinarsih, G. (2012). Pengaruh Kompensasi, Motivasi dan Komitmen Organisasional Terhadap Kinerja Karyawan Bagian Akuntansi (Studi Kasus Pada Perusahaan Manufaktur di Surabaya). The Indonesian Accounting Review, 2(2), 215-228.

Newstrom, J. W., \& Davis, K. (2007). Perilaku Dalam Organisasi (Ketujuh). Jakarta: Erlangga.

Novialumi, A. (2018). Pengaruh Pengembangan Karir Terhadap Kinerja Karyawan Melalui Mediasi Motivasi Kerja Karyawan di Nirwana Viberglass Bekasi. Journal Parameter, 3(1), 1-20.

Nugroho, A. D., \& Kunartinah. (2012). Analisis Pengaruh Kompensasi dan Pengembangan Karier terhadap Kepuasan Kerja dengan Mediasi Motivasi Kerja. Journal of Accounting and Banking, 19(2). Retrieved from http://www.unisbank.ac.id/ojs/index.php/fe8/article/view/940

Nupur, C., \& Barti, S. (2012). Chaudh. Internasional Journal of Business Trends and Technology, 2(4), 1-7.

Nurcahyani, N. M., \& Adnyani, I. G. A. D. (2016). Pengaruh Kompensasi dan Motivasi terhadap Kinerja Karyawan dengan Kepuasan Kerja sebagai Variabel Intervening. E-Jurnal Manajemen Unud, 5(1), 500-532.

Nzuve, S. N. M. (2007). Elements of Organizational Behavior. Nairobi: University of Nairobi Press.

Oduma, C., \& Were, S. (2014). Influence of Career Development of Employee Performance in The Public University, A Case of Kenyatta University. International Journal of Social Sciences Management and Entrepreneurship, 1(2), 1-16.

Patrick, H. A., \& Kumar, A. (2011). Career Management , Employee Development and Performance in Indian Information Technology 
Organizations. Business Management Dynamics, 1(5), 24-31.

Prabasari, I. G. A. A. M., \& Netra, I. G. S. K. (2013). Pengaruh Motivasi, Disiplin Kerja dan Komunikasi Terhadap Kinerja Karyawan Pada PT. PLN (Persero) Distribusi Bali. E-Jurnal Manajemen Unud, 2(4), 469-481. Retrieved from https://ojs.unud.ac.id/index.php/Manajemen/article/view/4774

Rayadi. (2012). Faktor Sumber Daya Manusia Yang Meningkatkan Kinerja Karyawan dan Perusahaan Di Kalbar. Jurnal EKSOS, 8(2), 114-119.

Riyanti, G. A. R., \& Sudibya, I. G. A. (2013). Pengaruh Motivasi dan Kompetensi terhadap Kinerja Karyawan pada RSU Dharma Usadha. E-Jurnal Manajemen Universitas Udayana, 2(6), 610-624.

Robbins, S. P., \& Judge, T. A. (2008). Perilaku Organisasi. Jakarta: Salemba Empat.

Sakti, R. R. (2013). Pengaruh Pengembangan Karir Terhadap Motivasi Kerja Karyawan (Studi Pada Toko Buku Gramedia Basuki Rachmat Malang). Universitas Negeri Malang.

Sarifah, W., Fathoni, A., \& Minarsih, M. M. (2016). Analisis Pengaruh Kepemimpinan Dan Pengembangan Karier Terhadap Kinerja Pegawai Melalui Komitmen Organisasi Pada PT. Nusantara Tour Semarang. Journal of Management, 02(02).

Satria, K., DW, H., \& Widiartanto. (2015). Pengaruh Budaya Organisasi, Pengembangan Karir dan Kompensasi Terhadap Kinerja Karyawan Bagian Pemasaran PT. Nyonya Meneer Semarang. Jurnal Ilmu Administrasi Bisnis, 4(4), 1-9.

Sungkono, P. (2013). Pengaruh Pengembangan Karir terhadap Motivasi Kerja Karyawan Pada PT. Excel Utama Indonesia Karawang. Jurnal Manajemen, 10(3), 1124-1134.

Umar, A. (2015). The Effect of Motivation and Career Development Against Employeesâ $€^{\mathrm{TM}}$ Performance and Job Satisfaction of the Governor Office South Sulawesi Province, Indonesia. International Journal of Management Sciences, 5(9), 628-638. Retrieved from http://rassweb.org/admin/pages/ResearchPapers/Paper 3_1497441403.pdf

Utama, M., Mujiati, N. W., \& Ardana, K. (2001). Buku Ajar Manajemen Sumber Daya Manusia. Denpasar: Upt Universitas Udayana.

Uzonna, U. R. (2013). Impact of motivation on employees' performance : A case study of CreditWest Bank Cyprus. Journal of Economics and International Finance, 5(5), 199-211. https://doi.org/10.5897/JEIF12.086

Zameer, H., Ali, S., Nisar, W., \& Amir, M. (2014). The Impact of the Motivation on the Employee' $\mathrm{s}$ Perfor mance in Beverage Industry of Pakistan. International Journal of Academic Research in Accounting, Finance and 
E-Jurnal Manajemen, Vol. 8, No. 10, 2019 : 6002-6021

Management

Sciences,

4(1),

293-298.

https://doi.org/10.6007/IJARAFMS/v4-i1/630 